\title{
Pharmaceutical Camel Products; Marketing Strategies for Successful International Penetration
}

\author{
Meqbel Aliedann ${ }^{1, \star}$, Mansour Alyahya1', Sneha Dhruvakumar², Nagaraja Sreeharsha ${ }^{3,4}$, \\ Santosh Fattepur ${ }^{5}$ \\ ${ }^{1}$ Department of Management, School of Business, King Faisal University, Al-Ahsa, SAUDI ARABIA. \\ ${ }^{2}$ Kashipathi Education Trust, Off Sarjapura Road, Bangalore, Karnataka, INDIA. \\ ${ }^{3}$ Department of Pharmaceutical Sciences, College of Clinical Pharmacy, King Faisal University, Al-Ahsa, SAUDI ARABIA. \\ ${ }^{4}$ Department of Pharmaceutics, Vidya Siri College of Pharmacy, Off Sarjapura Road, Bangalore, Karnataka, INDIA. \\ ${ }^{5}$ School of Pharmacy, Management and Science University, Seksyen, Shah Alam, Selangor, MALAYSIA.
}

\begin{abstract}
Background: This research aimed at how Saudi Arabia can be the global giant producer of pharmaceutical camel products using strategies for successful international penetration. In certain areas of Asia and Africa camel milk, urine, skin, and intestines are used as medicine from ancient days. Camel milk is the source of Vitamin C, B1, and B2. Heparin and gelatin are also extracted from the intestine and skin of the camel, respectively. While it is widely acknowledged that pharmaceutical companies are rapidly internationalizing. Much research on internationalization exists, but none of them concentrate pharma companies. Methods: As a result, we examine the current state towards internationalization, as well as the feasibility of an international policy, with a sample of 30 global pharmaceutical companies. For the eight years, we had collected data on total sales and regional drug revenues, as well as marketing, general, and administrative expenses. The Microsoft office 365 and IBM SPSS statistical program for Windows, edition 26.0, was used to perform all statistical calculations in this report. Results: Camel are pharmaceutically important animal and has great contribution in economy. Many Pharmaceutical companies in their home regions switched to being multinational, their TS remained unchanged from 2010 to 2017 (Paired t-test, $p=0.352$ ). However, companies that stayed focused on their home area increased their TS between 2010 and 2017 (Paired t-test, $p=0.053$ ). Expansion of Asia-Pacific and Others have a inverse impact on the expansion of Total Sales (home-region-oriented: $p<0.05, r=-0.629$; global: $p=0.161 r=-0.313$ ), Although the development of North America, on the other hand, had a direct correlation with the growth of Total sales (home-region-oriented: $p<0.01, r=0.818$; global: $p=0.094, r=0.408$ ). Conclusion: This paper contributes to the awareness of the importance of camel's pharmaceutical products and international penetration strategies of pharmaceutical companies.
\end{abstract}

Key words: Pharmaceutical companies, Camel Products, International strategies, Globalization, Public awareness, General text.

\section{INTRODUCTION}

The economy of the Kingdom of Saudi Arabia (KSA) depends largely on the reserves of oil and gases but as the population's increases day by day and the and maximum countries goes toward Solar energy, so the export of gas and oils are gradually lower down to fulfill this shortage it is necessary to designs different other sources of income like several deserts are present in Saudi Arabia and camel are the best animal to survive such types of areas. So, it is necessary to design different marketing strategies for global penetration. According to the word bank, Saudi Arabia considers a high-income country. In KSA livestock waste is also used as an energy source. ${ }^{1}$ The production of camel in KSA
Submission Date: 12-04-2021; Revision Date: 01-05-2021; Accepted Date: 03-05-2021

DOI: 10.5530/ijper.55.2.67 Correspondence: Dr. Meqbel Aliedan Department of Management, School of Business, King Faisal University, AlAhsa-31982, SAUDI ARABIA. Phone: +966538525000 Email id: maliedan@kfu. edu.sa

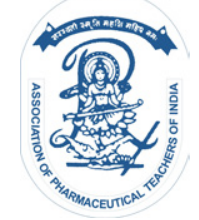

www.ijper.org 
decreases by almost 301717 heads was present in 2015 as compared to 248205 heads was in $2016 .^{2}$

Camel is a pharmaceutically important animal due to different reasons like human milk composition is similar to human milk as well. ${ }^{3}$ Vitamin $\mathrm{C}, \mathrm{B}_{1}$, and $\mathrm{B}_{2}$ are in high amounts in camel milk these vitamins can also be extracted and used in multivitamins in different pharmaceutical companies. ${ }^{4}$ Milk has also antibacterial, antidiabetic, and anti-hepatitis. ${ }^{5}$ It has also other therapeutic and beneficial characteristics like anticarcinogenic, anti-hypertensive. ${ }^{6}$ It inhibits the contamination due to the presence of lactoperoxidase, $\mathrm{H}_{2} \mathrm{O}_{2}$, lactoferrin, immunoglobulin, lysozymes, hydrogen peroxide, and free acid. ${ }^{7}$ From the camel's milk, some hydrolysates are extracted that are anti-proteolysis. ${ }^{8}$ In the past camel's milk are used for the medication of certain diseases like jaundice, asthma, and tuberculosis because of the presence of certain natural components. ${ }^{9}$ Gelatin is an important component used in food industries as well as in nonfood industries like the tannin industry. Nowadays it has much importance in the pharmaceutical industries because it is used to cure osteoarthritis, skin aging, osteoporosis, obesity, and brittle nail as well. ${ }^{10,11}$ Gelatin was produced from different animals like pigskin and many others, but their usage is a religious issue, so the gelatin extracted from camel skin is most favorable and beneficial. Hence because of these beneficial characteristics, these are used in different pharmaceutical companies. ${ }^{12}$ Heparin is also an important component of pharmaceutical drugs used as anti-coagulant ${ }^{13}$ as these are heterogeneous anionic polysaccharides and are also known as glycosaminoglycan. they are easily be extracted from the camel intestine ${ }^{14}$ lungs. ${ }^{15} \mathrm{~A}$ unique type of antibody is present in camel blood. They lack a light chain, so antibody comprises of the only single domain that is variable one and commonly known as nanobody. They are important pharmaceutical components using for the screening breast cancer patient. ${ }^{16}$

The business model of pharmaceutical companies depends on investing in research and development in this way making novel things, delivering these products collecting return as profit. ${ }^{17}$ It's widely accepted that novel things generate more profit, in a similar way pharmaceutical companies invest more in research. ${ }^{18}$ Traditionally pharmaceutical companies are in more benefits because of the addition of higher values through research and less manufacturing costs. ${ }^{19}$ However pharmaceutical companies nowadays facing problems with respect to their business. Majorly pressure on industrial profitability as the healthcare budget of developed countries increases so they are regulating pharmaceutical prices. ${ }^{20,21}$ The other challenge for pharmaceutical industries is for launching new products its efficiency is checked through clinical trials but unfortunately, success rates declined. ${ }^{22}$ "Target-to-hit" success ratio to introduce a medicine was only $4 \%$, and an average of 1778 million USD is the cost to launch over 13 years. ${ }^{23}$

Given this framework, the pharmaceutical industry is seen to be increasingly internationalizing, to raise revenue through overseas expansions while reducing research and development costs through global trials. ${ }^{24,25}$ Since technology and internationalization standardize customer preferences, high rank pharmaceutical companies shift from personalized medicine to globally standardized medicine. ${ }^{26}$ Internationalization enables a company to benefit from economies of scale. ${ }^{27}$ Previous research on co-relation firm's success metrics and its globalization have seen a high range of outcomes, covering all positively and negatively co-relation, and no relationships at all ${ }^{28,29}$ Many well-known international companies fail caused by a lack of adaptation, according to the author, who points out that variations in consumer tastes, finances, and purchasing habits, as well as environmental factors like legislation, necessitate international customization. ${ }^{30}$ The rising complexities of multinational markets make it difficult to adapt successfully to consumer demands. ${ }^{31}$ In conclusion, when it comes to promoting internationalization for sustainability, there seems to be a discussion on how the global pharmaceutical industry ought to pursue a global strategy to collect revenues across the world. On the premise that consumer preferences are similar everywhere, or perhaps a global strategy for generate profit in a particular region on the premise that consumer preferences are specific regions.

There are two major parts in our research firstly aware the importance of pharmaceutical products of camel and packing these pharmaceutical products and deliver them globally. And the other major thing is the use of different techniques for global penetration and generate more revenue. As a result, we use evidence from 30 global pharmaceutical firms from 2010-2017 to examine the impact of foreign policy in the pharmaceutical industry. In this research, we describe international strategy as a technique for optimizing total sales (TS) by managing the geographic distribution of revenue across regions, and on the bases of geographical regions we divide pharmaceutical companies into four different parts. ${ }^{32}$ This classification relay on the trade power concept. ${ }^{33}$ The trade was geographically dependent and expand to broader areas like the Asia Pacific, Europe, and America. ${ }^{34}$ Most companies expand into new markets with a product that is somewhat close to what 
they sell in home grounds, which are using to gauge international consumer approval of their offerings and, as a result, move the entire manufacturing process to different markets. ${ }^{35}$ Pharmaceutical firms, on the other hand, are unable to measure approval of their medicinal products in the same way. In general, medicines or any other medical products required the approval of the host countries for that purpose a large significant data is required that takes extensive time with no assurance of technical success. Pharmaceutical companies must obtain regulatory approval from another country to alter the characteristics of their medicinal products, even though they are aware of the country's or regions' acceptance.

\section{Methodology}

Our study focuses on two parts one is the camel's pharmaceutical products secondly and the most important part is strategies for international penetration. Camel has many pharmaceutical products milk products of camel is collected vitamin and other important things are extracted using different methods. Gelatin, heparin is also extracted from camel skin and intestines respectively from the slaughterhouse. One of the important factors is the packaging of pharmaceutical products. For these products and their packaging, we contact different multinational companies and check their progress from annual reports.

\section{Data}

Focused on global medicine sales during 2010-2017, we approached the 50 largest global pharmaceutical industries. ${ }^{36}$ For the eight years, we had collected data on total sales and regional drug revenues, as well as marketing, general, and administrative expenses. We counted sales of medicine related to human beings and omitted other medicine. Our major focus was on their strategies how they globalized from starting home grounds to globalize. The Financial reports as well as Annual reports, like the $20-\mathrm{F}$ and $10-\mathrm{K}$ forms, were used as data sources. The data that was in other currencies we first convert into USD based on International monetary fund statistics. ${ }^{37}$ We collected data from 30 global pharmaceutical companies out of 50 major international pharmaceutical companies as mentioned in Table 1.

\section{Classification of Internationalization}

Based on Verbeke's and Rugman classification, we categorized the 30 companies into the four categories mentioned previously, ${ }^{32}$ and added a domestic group to round out the list (less than 10 percent of revenue in foreign countries)..$^{38,39}$ As of 2014, North America accounted for approximately $40 \%$ of global pharmaceutical sales, followed by Europe (30\%) and Asia-Pacific (30\%). ${ }^{34}$ As a result, our three research areas are formed. We did not change net sales by local market size since the three regions' economies are virtually similar.

\section{Internationalization Effectiveness}

Previous studies on the success of internationalization lacked a control group. ${ }^{28,29}$ There has not been a detailed comparison of the success of multinational strategies. As our research is limited to 30 pharmaceutical companies, we use case research to point out the effects of different strategies on the globalization. it creates a sense to pick marginal forms. ${ }^{40}$ As a monitor, we compare multinational companies to companies focused on their home regions as a control of the two extreme foreign strategies.

\section{Global Companies versus Home-Region-Oriented Companies}

We used two classes of companies with 2017 data to determine the efficacy of an international penetration strategy. Home-oriented companies and global companies as a control. We compare the total sale of both international pharmaceutical companies and home region companies as this is the best indicator for understanding the effectiveness of the international strategies. If there were no statistical variations between both the groups, we compared Home region companies to global companies in terms of the altered total sale, which we decided by dividing total sale using selling general and administrative (SG\&A) costs, or sales and marketing efficiency. SG\&A investments usually

Table 1: Sample of Pharmaceutical companies list.

\begin{tabular}{|c|c|c|}
\hline Asia & Europe & America \\
\hline Eisai & GlaxoSmithKline & $\begin{array}{c}\text { Johnson and } \\
\text { Johnson }\end{array}$ \\
\hline $\begin{array}{c}\text { Sumitomo } \\
\text { Dainippon }\end{array}$ & Bayer & Alexion \\
\hline Astellas Pharma & Sanofi & Gilead Sciences \\
\hline Shionogi & Roche & Biogen \\
\hline Teva \\
Pharmaceutical & Merck KGaA & $\begin{array}{c}\text { Bristol-Myers } \\
\text { Squibb }\end{array}$ \\
\hline Takeda & Novartis & Mylan \\
\hline Daiichi Sankyo & Boehringer Ingelheim & Eli Lilly \\
\hline & Shire & Merck \& Co \\
\hline & AstraZeneca & Pfizer \\
\hline & UCB & Celgene \\
\hline & Novo Nordisk & AbbVie \\
\hline & & Amgen \\
\hline
\end{tabular}


increase the revenue hence logically total sales increase when SG\&A increase. ${ }^{41}$ The Shapiro-Wilk test was used to determine if the data met the normality criterion. When the data were normal, we used the Levene test to conduct the Welch's t-test, or even the Student's t-test, based on homoscedasticity. A Mann-Whitney U test was used when the study did not meet the criteria for normality. The dipole of 0.05 was used as a predetermined significance level. The Microsoft office 365 and IBM SPSS statistical program for Windows, edition 26.0, was used to perform all statistical calculations in this report.

\section{Companies Shift to becomes Global versus Home Region companies' comparison.}

To assess the impact of a change in international strategy on performance (like adjustment in the total sale from 2010-2017), we used 2017 data and divide companies into two groups: those that shifted to becoming global (like companies that were domestic in 2010 and now shifted toward global or bi-regional) as well as those who remain domestic as control. The Shapiro-Wilk test was used to determine if the data met the normality criterion. We used a paired t-test with a pre-set level of significance since these data were regular ( $p$-value of 0.05).

\section{Growth Pattern}

We use a pre-set significance level to test the Pearson correlation coefficient among the change in total sales from 2010-2017 as well as the change in the percentage of the local regions to understand a rising factor in the TS of multinational industries and home-regioncompanies (both sides $P$-value 0.5 ).

\section{RESULTS}

\section{Pharmaceutical industry internationalization}

The subsequentclassifications and group transformations are shown in Table 2. In $201740 \%$ of companies (12) were global and $33 \%$ of companies (10) were homebased. No domestic companies were present at that time. From 2010 to 2017 the home region companies decrease in number from 15 to 10 while the increase was seen in international pharmaceutical companies from 8 to 12. One host-region-oriented company, three home-region-oriented companies, and two bi-regional companies become global while 2 global companies become host-region-oriented or bi-regional. While onethird of the pharmaceutical industry's largest companies were still anchored in their home regions, the industry's largest companies were moving to a global orientation.
This table shows the $201740 \%$ of companies (12) were global and $33 \%$ of companies (10) were home-based. No domestic companies were present at that time. From 2010 to 2017 the home region companies decrease in number from 15 to 10 while the increase was seen in international pharmaceutical companies from 8 to 12 .

\section{Comparison of Home-Region-Oriented companies Versus Global Companies}

Based on statistical data from 2017, Figure 1 compares overall revenue and sales and management (S\&M) efficiency between multinational and home-regionoriented companies in 2010 and 2017. In 2010, there were no statistical variations in total sales (MannWhitney U test, Welch's t-test; $p=0.456, p=0.069$ respectively). Global companies' S\&M productivity, on the other hand, was lower than that of companies based on their home area (Student's t-test, $p<0.05$ ). In 2017, however, there was no statistically significant difference in overall revenues between global and home-regionoriented pharmaceutical companies (Student's t-test, $p=0.409)$. Our findings show that an international or home-region orientation approach increased modified TS effectiveness.

\section{Global and home stayed companie's comparison}

In 2010, 15 pharmaceutical firms were based in their native country. Five companies move toward
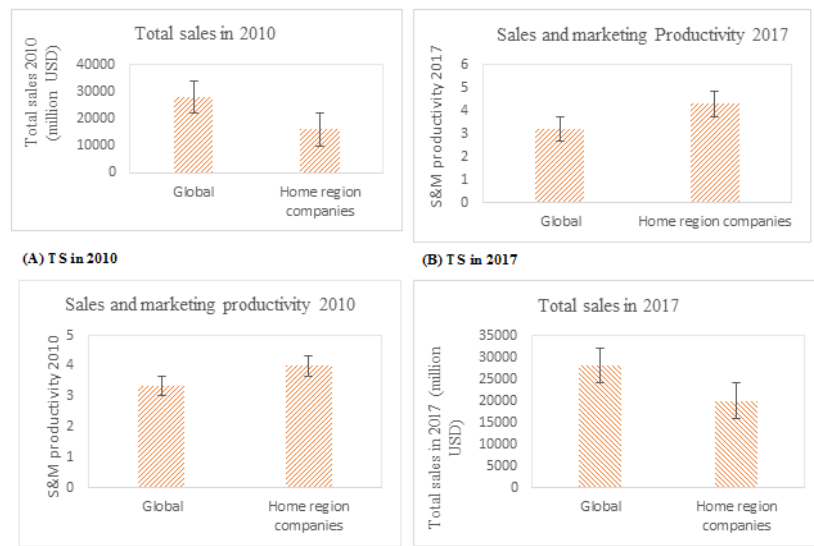

(B) TS in 2017

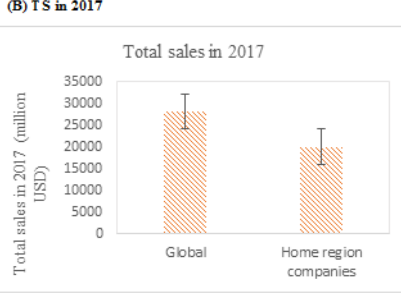

(D) S\&M Productivity 2017

(C) S\&M Productivity 2010

Figure 1: Comparison of Home-region-oriented companies versus global companies in sales, marketing productivity, and total sales. (a) Total sales in 2010 nine are homeregion-oriented companies while 12 are global companies. (b) this shows total sales in 2017 nine are home-region oriented while 12 are global companies. (c) shows sales and marketing productivity $\mathbf{2 0 1 0}$ eleven companies are global nine companies are home-region-oriented while one from each category cannot provide selling and marketing productivity. (d) sales and marketing productivity 2017 eleven are global companies while nine are home-region-oriented companies and one company cannot provide sales and marketing productivity. $p<0.05$ 
multinational companies. In 2017, one organization became host-oriented, while nine others stayed homeregion-oriented, as seen in Table 1. Figure 2 highlights the differences in TS between companies that go global as well as those who stay regionally centered between 2010 to 2017. Even though many businesses in their home regions switched to being multinational, their TS remained unchanged from 2010 to 2017 (Paired t-test, $p=0.352)$. However, companies that stayed focused on their home area increased their TS between 2010 and 2017 (Paired t-test, $p=0.053$ ). We found no evidence that changing the foreign approach had a positive effect on performance effectiveness.

\section{Home-Oriented pharmaceutical companies versus Global companies' growth pattern}

Figure 3 illustrates the relationship between the change of total sales as well as the change in regional sales contribution to total sales. Expansion of Asia-Pacific and Others have a inverse impact on the expansion of Total Sales (home-region-oriented: $p<0.05, r=-0.629$; global: $p=0.161 \mathrm{r}=-0.313$ ), Although the development of North America, on the other hand, had a direct correlation with the growth of Total sales (homeregion-oriented: $p<0.01, \mathrm{r}=0.818$; global: $p=0.094$, $r=0.408)$. Furthermore, the proportion shift in North America and Asia-Pacific/Other regions was inversely related (home-region-oriented: $p<0.01, \mathrm{r}=-0.843$, global: $p<0.01, \mathrm{r}=-0.713)$. Both groups' growth rates are considered close in general. The rise in total sales for both groups was supported by an improvement in the proportion of local sales in North America.

\section{DISCUSSION}

Table 2 shows that a high proportion of pharmaceutical companies moves toward global one from (2010-2017). While it may not be necessary to specifically relate the findings of this study to those of previous research, the pharmaceutical industry appears to be more proactive than other industries. ${ }^{42}$ This study supported all those firms and industries that are related to biotechnology and pharmacology for its expansion to all other countries using different strategies. ${ }^{43}$ However, as seen in Table 2 , the proportion of companies focused on their home area is comparable to that of global companies. To look at it another way, some pharmaceutical companies are already rooted in their home regions. Internationalization is divided into three stages, according to the capabilities-based organizational growth like sensing, seizing, mobilizing and transferring. ${ }^{44,45}$ Individual pharmaceutical companies must fulfill environmental and internal business standards for internationalization at the mobilizing, seizing, and operating, or changing phases. They may also understand that a pharmaceutical product that is dominant in a single geographic market might not be appealing to consumers worldwide. Given these obstacles, a pharmaceutical company would need sophisticated global transferability of scientific expertise, international management skills, and unique strategic strategy for each country. ${ }^{46}$ Even though the International Committee for the Harmonization of Technical Requirements for Pharmaceutical Products for Human Use $(\mathrm{ICH})$ is working on legal context harmonization to adapt to the globalization of developing drugs, processing, and delivery. As a result,

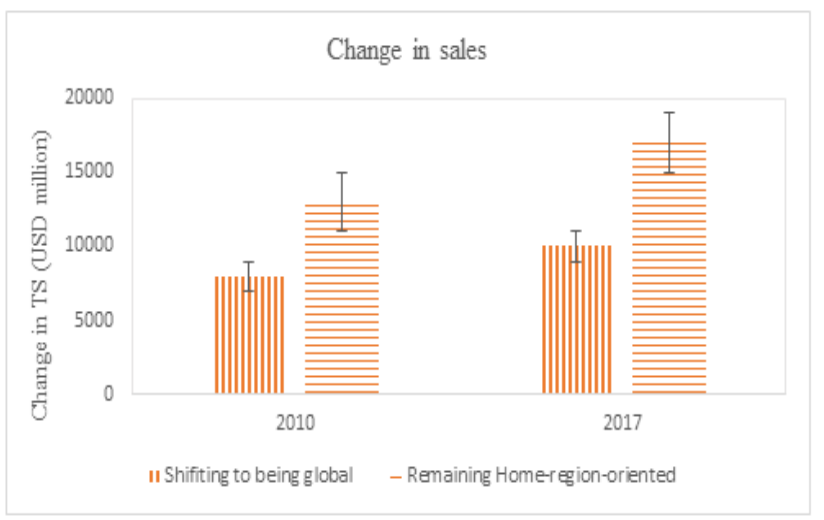

Figure 2: Comparison of firms in total sales that move to be global and those stays home-region-oriented. Five companies shift toward being global while nine remained home-regionoriented. $P<0.1$

\begin{tabular}{|c|c|c|c|c|c|c|}
\hline \multicolumn{7}{|c|}{ Table 2: Internationalization of Pharmaceutical industry. } \\
\hline Category & Global & $\begin{array}{c}\text { Home- } \\
\text { region }\end{array}$ & $\begin{array}{c}\text { Host- } \\
\text { region }\end{array}$ & $\begin{array}{c}\text { Bi- } \\
\text { regional }\end{array}$ & Unknown & 2017 \\
\hline Global & 6 & 3 & 1 & 2 & 0 & $12(40 \%)$ \\
\hline Home-region & 0 & 9 & 0 & 0 & 1 & $10(33 \%)$ \\
\hline Host-region & 1 & 1 & 2 & 0 & 0 & $4(13 \%)$ \\
\hline Bi-regional & 1 & 2 & 0 & 1 & 0 & $4(13 \%)$ \\
\hline Unknown & 0 & 0 & 0 & 0 & 0 & $0(0 \%)$ \\
\hline 2010 & $8(27 \%)$ & $15(50 \%)$ & $3(10 \%)$ & $3(10 \%)$ & $1(3 \%)$ & \\
\hline
\end{tabular}




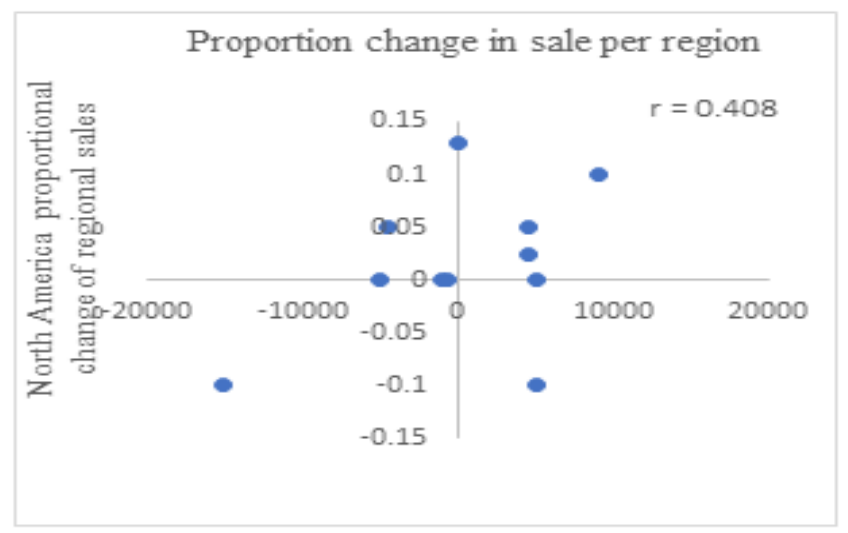

Proportion change in sale per region

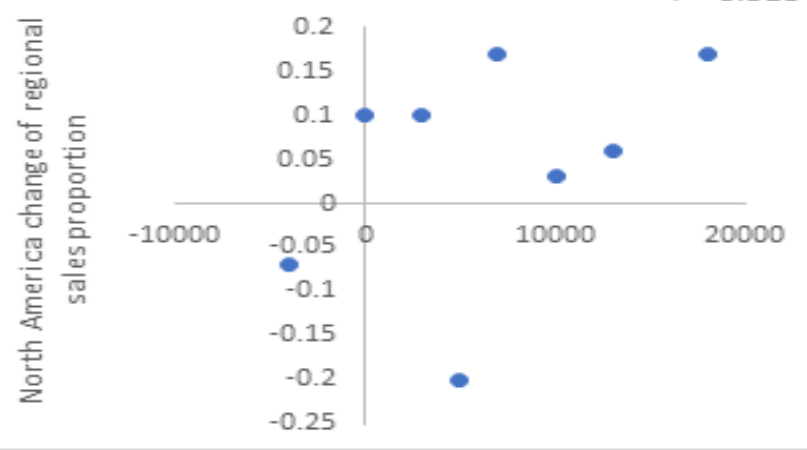

Proportion change in sale per region

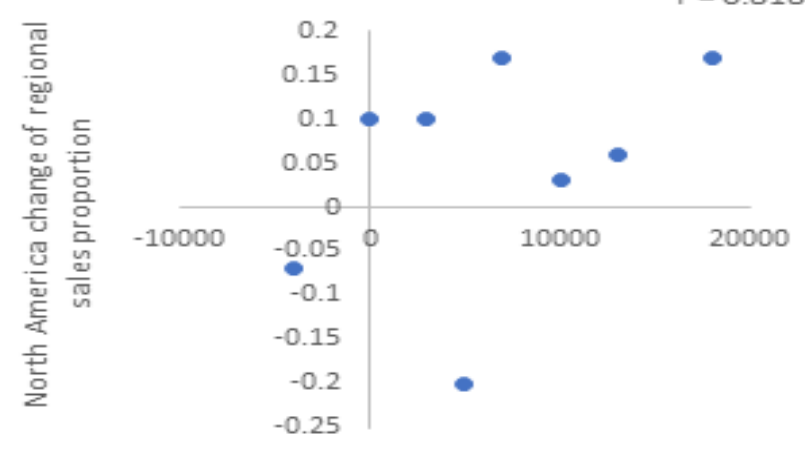

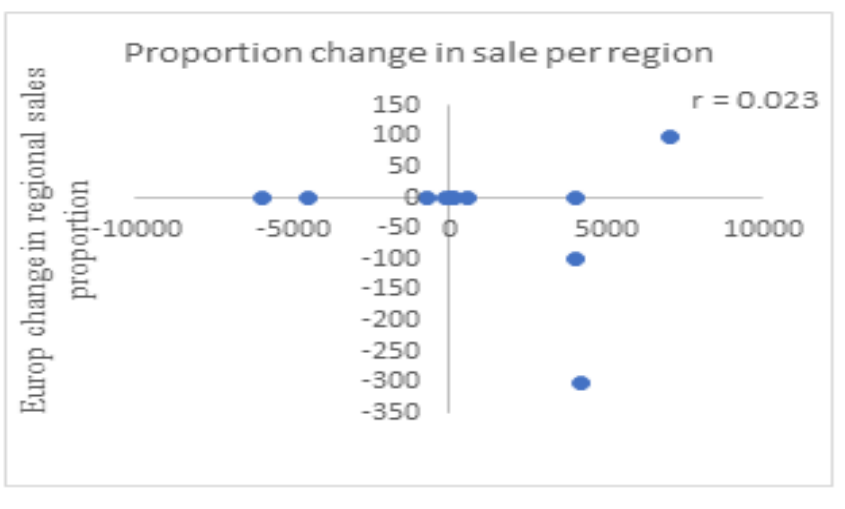

Proportion change in sale per region

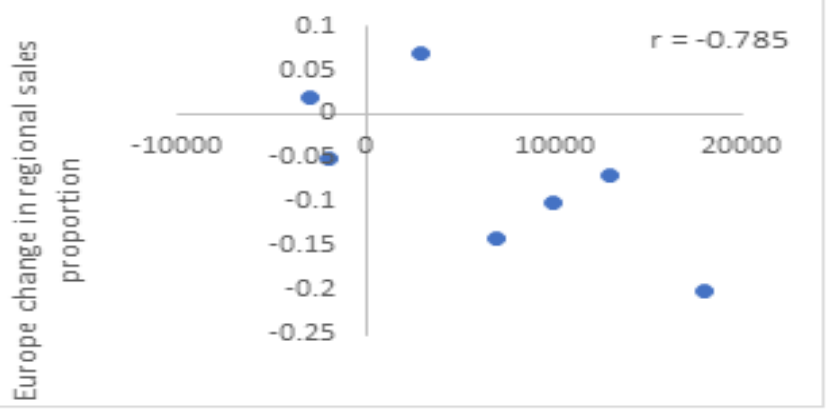

Proportion change in sale per region

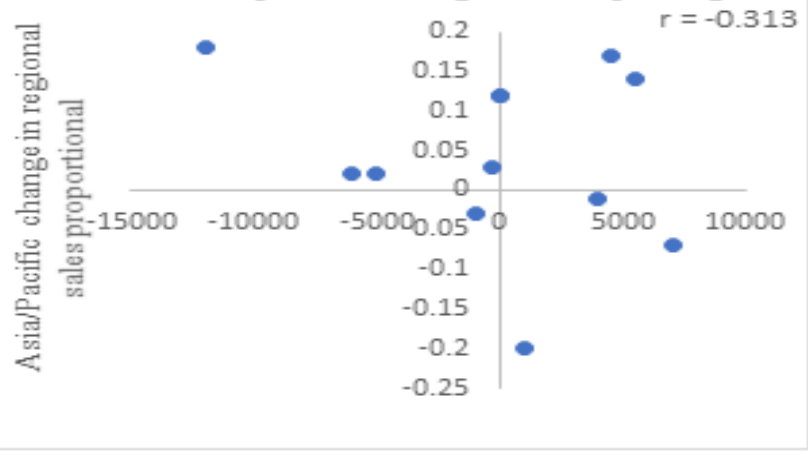

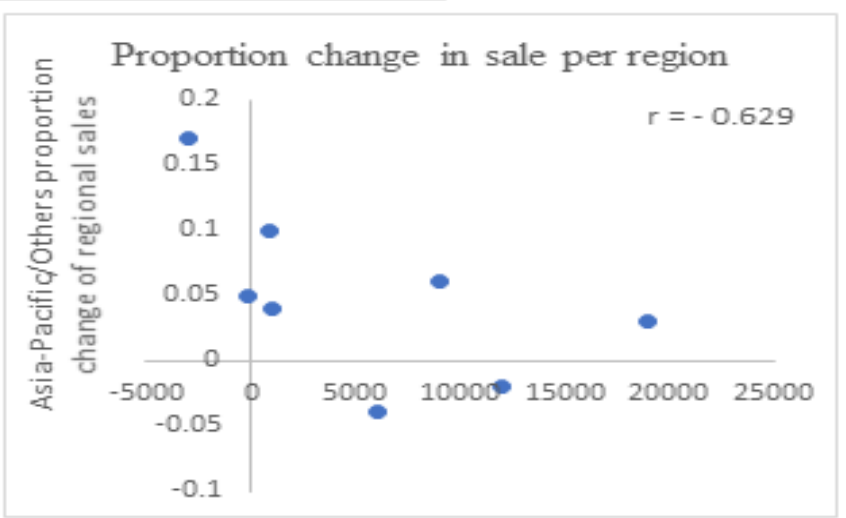

\section{Change in TS (US D million)}

(a) G lobal companies
Change in TS (US D million)

(b) Home-region-oriented companies

Figure 3: The growth pattern of Home-region-oriented and global companies from 2010-2017. The change of total sales (2010-

2017 ) is represented on X-axis, while the proportional shift in sales per region (2010-2017) is shown on Y-axis. (a) Twelve number of global companies (b) eight number of home-region companies while two firms cannot provide data. $p<0.05, p<0.01$. 
finding a one-size-fits-all answer in all regions appears to be very difficult. Eeven though there is no variation in the number of pharmaceutical companies (more than 10,000 million USD sales in 2017) among home-regionoriented companies and global.

We investigated the effects of a change in global strategy (i.e., moving to global) on performance effectiveness, but found no positive results, as seen in Figure 2. Then, as a control, we correlated companies that moved toward a bi-regional orientation or global to companies that stayed based on their home area. However, there was no statistical difference (data not shown, Student's t-test; $p=0.070)$, companies that stayed in home region have high in S\&M efficiency in 2017 than others who just moved to an international business. As seen in Figure 1, this pattern was close to what we saw in global vs. home region pharmaceutical companies. One explanation is that they are looking for a different advantage from the rise in international regional revenues, which is known as multinationalism. ${ }^{47}$ Multinationalism has a positive relationship with Tobin's q (TQ), that characterized the co-relation of a company's market values to the cost of replacing its properties. ${ }^{48}$ Similarly, The international nature of Fortune Global 500 firms has a positive impact on TQ. ${ }^{49}$ Companies with an S-curve correlation between multinationalism and efficiency, like TQ, meet the S-curve in firm profitability, like return on sales. ${ }^{28,49}$

In this analysis, we looked at the shift in TS and sales in each region and discovered that home-region-oriented and global pharmaceutical companies have similar growth trends. Simply put, focusing on pharmaceutical companies as an international strategy for TS growth is successful. The integration-responsiveness model is among the most common approaches to global expansion among many theories. ${ }^{50}$ Using this model, we can demonstrate how the pharmaceutical companies are distinct. Since drug modification necessitates a high level of responsiveness, it is restricted because of a countless of data, significant cost, approval, as well as investment of lengthy time. Furthermore, increasing dynamics of foreign companies make it impossible to respond effectively to a variety of market demands. ${ }^{31}$ All pharmaceutical companies must figure out how to gain global competitiveness through international versatility, learning skills, and inventions.

\section{CONCLUSIONS AND IMPLICATIONS}

\section{Research Conclusion}

We concluded that camels' products are highly beneficial for human health. Different pharmaceutical products are made from his skin intestine and milk as well. A public awareness is necessary to understand its importance. We also focused on the state of globalization in pharmaceutical companies and how successful it is. Our analysis has led us to three big conclusions. Firstly, concluded that the pharma industries appear to be high proactive in pursuing a global strategy and move into an international approach, although few of the major firms stayed rooted in their home country. This finding adds to ancient studies by presenting updated data on the state of globalization in the pharma companies from the last few years, one of the aims of our study. Secondly, we observed global pharma industries did advantage from a foreign distribution strategy in terms of S\&M productivity and TS. This result adds to our understanding of the efficacy of a foreign policy using a statistical approach, which is another aim of our study. Finally, we discovered that concentrating on regional revenues helps global pharmaceutical companies raise their TS. This may mean that even an international method to improve sales in a specific region based on the premise that consumer needs vary by region is a better strategy for encouraging internationalization for long-term development.

\section{Implication, Limitation, and future work}

This research has implications for understanding the pharmaceutical industry's long-term development from the standpoint of internationalization. ${ }^{28,44,45}$ In terms of practical consequences, pharmaceutical companies should evaluate specific markets to increase revenue by leveraging the benefit of being able to respond to changing consumer needs. We examined the efficacy of a global strategy and discovered that a focus on the home market has aided revenue growth. However, changing a strategy does not appear to be easy, as our research indicates that pharmaceutical firms are transitioning to a global focus. The context of management decisions is becoming more complicated than in the previous, and a company must identify the activities that provide the company's business model, the areas in which the company's resources and/or value-adding activities are distributed, and the management techniques of the operations when creation planned decisions on a business model. They emphasize that, in the current competitive environment, location decisions are becoming increasingly important. As a result, prospective studies that look at international penetration from either the perspective of research or development must consider the full scope of a business model's implications for the pharmaceutical industry. 


\section{Funding}

The authors extend their appreciation to the Deputyship for Research and Innovation, Ministry of Education in Saudi Arabia for funding this research work through the project number IFT20191.

\section{ACKNOWLEDGEMENT}

The authors thank the Deanship of Scientific Research, King Faisal University, Al-Ahsa, Saudi Arabia for their support.

\section{CONFLICT OF INTEREST}

The authors declare no conflicts of interest. The funders had no role in the design of the study; in the collection, analyses, or interpretation of data; in the writing of the manuscript, or in the decision to publish the results.

\section{ABBREVIATIONS}

KSA: Kingdom of Saudi Arabia; USD: United States dollar; TS: Total sales; SG and A: Selling General and Administrative; SPSS: Statistical Package for the Social Sciences; IBM: International Business Machines; ICH: International Committee for the Harmonization.

\section{REFERENCES}

1. Abdel-Rahman EH, Alzahrani FS, Sulieman AMEH. Potential of Camel Dung as Promising Organic Manure in Saudi Arabia. Advancements in Life Sciences. 2020;7(4):202-7.

2. Elzaki RM, Ahmed SH, Al-Mahish MA. Camel production in Kingdom of Saudi Arabia: Economic and environmental impacts. J Fundam Appl Agric. 2018;3(3):602-8.

3. Konuspayeva GS. Camel milk composition and nutritional value. Handbook of Research on Health and Environmental Benefits of Camel Products: IGI Global; 2020.;15-40.

4. AIGhsyar MA, Salem SA, Ahmad SH. Studies on Physiochemical and Functional Properties of Protein Co-Precipitates from Camel's and Goat's Milk. Health Science Journal. 2018;12(5):1-7.

5. Agrawal RP, Dogra R, Mohta N, Tiwari R, Singhal S, Sultania S. Beneficial effect of camel milk in diabetic nephropathy. J Acta Biomed. 2009;80(2):1314.

6. Ayoub MA, Palakkott AR, Ashraf A, Iratni R. The molecular basis of the anti-diabetic properties of camel milk. Diabetes Research Clinical Practice. 2018;146:305-12.

7. El-Fakharany EM, Abedelbaky N, Haroun BM, Sánchez L, Redwan NA, Redwan EM. Anti-infectivity of camel polyclonal antibodies against hepatitis $C$ virus in Huh7: 5 hepatoma. J Virology Journal. 2012;9(1):1-9.

8. Salami M, Moosavi-Movahedi AA, Moosavi-Movahedi F, Ehsani MR, Yousefi $\mathrm{R}$, Farhadi M, et al. Biological activity of camel milk casein following enzymatic digestion. J Journal of Dairy Research. 2011;78(4):471.

9. Abdelgadir WS, Ahmed TK, Dirar HA. The traditional fermented milk products of the Sudan. J International Journal of Food Microbiology. 1998;44(1-2):1-13.

10. Alipal J, Pu'ad NM, Lee T, Nayan N, Sahari N, Basri H, et al. A review of gelatin: Properties, sources, process, applications, and commercialisation. J Materials Today: Proceedings. 2021.

11. Irwanto D. Purification of Gelatin from Leather Waste into Pharmaceutical Grade Gelatin. J Available at SSRN 3800632. 2021.
12. Alwi Z. Halal Analysis Principle for Food and Pharmaceutical: A Case Study of Gelatin. 2020.

13. Dey $\mathrm{S}$, Lo HJ, Wong $\mathrm{CH}$. An efficient modular one-pot synthesis of heparinbased anticoagulant idraparinux. J Journal of the American Chemical Society. 2019;141(26):10309-14.

14. Warda M, Gouda EM, Toida T, Chi L, Linhardt RJ. Isolation and characterization of raw heparin from dromedary intestine: evaluation of a new source of pharmaceutical heparin. Comparative Biochemistry Physiology Part C: Toxicology Pharmacology. 2003;136(4):357-65.

15. Almeman A, Abdulmajed K, Eid EE. Detection and Extraction of Heparin from Camel Lungs. J Current Pharmaceutical Biotechnology. 2019;20(6):476-82.

16. Moghimi SM, Rahbarizadeh F, Ahmadvand D, Parhamifar L. Heavy chain only antibodies: a new paradigm in personalized HER2+ breast cancer therapy. J Biolmpacts. 2013;3(1):1.

17. Booth B, Zemmel R. Prospects for productivity. Nature Reviews Drug Discovery. 2004;3(5):451-6.

18. Kneller R. The importance of new companies for drug discovery: Origins of a decade of new drugs. Nature Reviews Drug Discovery. 2010;9(11):867-82.

19. Ogrean C. A Snapshot of the World of Global Multinationals: An Industry Based Analysis of Fortune Global 500 Companies. J Studies in Business Economics. 2017;12(2):136-54.

20. Angelis A, Lange A, Kanavos P. Using health technology assessment to assess the value of new medicines: Results of a systematic review and expert consultation across eight European countries. The European Journal of Health Economics. 2018;19(1):123-52.

21. Teramae F, Yamaguchi N, Makino T, Sengoku S, Kodama K. Holistic costeffectiveness analysis of anticancer drug regimens in Japan. Drug Discovery Today. 2020;25(2):269-73.

22. Smietana K, Siatkowski M, Møller M. Trends in clinical success rates. Nature Reviews Drug Discovery. 2016;15(6):379-80

23. Paul SM, Mytelka DS, Dunwiddie CT, Persinger CC, Munos BH, Lindborg SR, et al. How to improve R\&D productivity: The pharmaceutical industry's grand challenge. Nature Reviews Drug Discovery. 2010;9(3):203-14

24. Moorkens E, Meuwissen N, Huys I, Declerck P, Vulto AG, Simoens S. The market of biopharmaceutical medicines: A snapshot of a diverse industrial landscape. J Frontiers in Pharmacology. 2017;8:314.

25. Tannoury $M$, Attieh $Z$. The influence of emerging markets on the pharmaceutical industry. J Current Therapeutic Research. 2017;86:19-22.

26. Levitt $\mathrm{T}$. The globalization of markets. Readings in international business: $\mathrm{A}$ decision approach. 1993;249:249-52.

27. Kogut B. Designing global strategies: Comparative and competitive valueadded chains. Sloan Management Review. 1985;26(4):15.

28. Contractor FJ, Kundu SK, C-CJJoibs H. A three-stage theory of international expansion: The link between multinationality and performance in the service sector. Journal of International Business Studies. 2003;34(1):5-18.

29. Oh $\mathrm{CH}$, Contractor F. A regional perspective on multinational expansion strategies: Reconsidering the three-stage paradigm. British Journal of Management. 2014;25:S42-59.

30. Kotler P. Global standardization—courting danger. J Journal of Consumer Marketing. 1986.

31. Bartlett CA, Ghoshal S. Managing across borders: The transnational solution: Harvard Business Press; 2002.

32. Rugman AM, Verbeke A. A perspective on regional and global strategies of multinational enterprises. J Journal of International Business Studies. 2004;35(1):3-18.

33. Ohmae K. Triad power: The coming shape of global competition Free Press. J New York; 1985.

34. Gautam A, Pan X. The changing model of big pharma: Impact of key trends J Drug Discovery Today. 2016;21(3):379-84.

35. Farrell D. Beyond offshoring. J Harvard Business Review. 2004;82(12):82-90

36. Christel M. Pharm Exec's Top 50 Companies 2017. J Pharmaceutical Executive. 2017;37(6):4

37. Qian G, Khoury TA, Peng MW, Qian Z. The performance implications of intra-and inter-regional geographic diversification. J Strategic Management Journal. 2010;31(9):1018-30.

38. Geringer MJ, Beamish PW, DaCosta RC. Diversification strategy and internationalization: Implications for MNE performance. J Strategic Management Journal. 1989;10(2):109-19. 
Qian G, Khoury TA, Peng MW, Qian Z. The performance implications of intraand inter-regional geographic diversification. Strategic Management Journal. 2010;31(9):1018-30.

40. Pettigrew AM. Longitudinal field research on change: Theory and practice. J Organization Science. 1990;1(3):267-92.

41. Weiss D, Naik P, Weiss R. The'big pharma'dilemma: Develop new drugs or promote existing ones?. J Nature Reviews Drug Discovery. 2009;8(7):533-4.

42. Rugman $A M$, Verbeke A. A perspective on regional and global strategies of multinational enterprises. Journal of International Business Studies. 2004;35(1):3-18.

43. Oh CH, Kim M, Shin J. Paths and geographic scope of international expansion across industries. International Business Review. 2019;28(3):560-74.

44. Doz Y, Santos J, Williamson P. From global to metanational: How companies win in the knowledge economy. J Ubiquity. 2001;2001(12):2
45. Teece DJ. A dynamic capabilities-based entrepreneurial theory of the multinational enterprise. Journal of International Business Studies. 2014;45(1):8-37.

46. Jouida $\mathrm{S}$, Bouzgarrou $\mathrm{H}$, Hellara $\mathrm{S}$. The effects of activity and geographic diversification on performance: Evidence from French financial institutions. Research in International Business Finance. 2017;39:920-39.

47. Yang $\mathrm{Y}$, Driffield N. Multinationality-performance relationship. Management International Review. 2012;52(1):23-47.

48. Tobin J. A general equilibrium approach to monetary theory. Journal of Money, Credit Banking. 1969;1(1):15-29.

49. Oh HM. Market value creation through international expansions: Evidence from Fortune Global 500 firms. J Journal of International Trade Commerce. 2016;12(6):157-67.

50. Parahalad C, Doz Y. The Multinational Mission: Balancing Local Demands and Global Vision. New York: The Free Press; 1987.

\section{SUMMARY}

Saudi Arabia can be the global giant producer of pharmaceutical camel products using strategies for successful international penetration. Camel are pharmaceutically important animal and has great contribution in economy. The research contributes to the awareness of the importance of camel's pharmaceutical products and international penetration strategies of pharmaceutical companies.

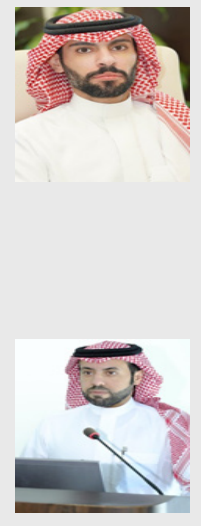

About Authors

Meqbel Mishary ALIEDAN, PhD, is an associate professor at the School of Business, King Faisal University. His areas of expertise include international business, strategic management, talents development, and Human Resources management. Dr. Aliedan is currently the Vice President of Studies, Development \& Community Engagement at King Faisal University and has provided a series of consultations and participated in multiple projects at national \& international levels. $\mathrm{He}$ also has different research outputs in the fields of SMEs internationalization, international franchising, internationalization entry modes, the dynamic capability of international firms, commercial diplomacy and business research.

Dr. Mansour AlYahya is an Assistant Professor in Marketing at King Faisal University and is interested in digital marketing and the use of technology in tourism. He is also an active researcher in the field of consumer confusion.

Cite this article: Aliedan M, Alyahya M, Dhruvakumar S, Sreeharsha N, Fattepur S. Pharmaceutical Camel Products; Marketing Strategies for Successful International Penetration. Indian J of Pharmaceutical Education and Research. $2021 ; 55(2): 629-37$. 